\title{
Detecting the Occurrence of Campylobacter jejuni in Chicken Meat by PCR in Retail Outlets of Chennai, India
}

\author{
S. Satheesh Raja*, V. Apparao, R. Narendra Babu and N. Balamurugan
}

Department of Meat Science and Technology, Madras Veterinary College, Chennai, India

*Corresponding author

\section{A B S T R A C T}

\begin{tabular}{|l|}
\hline K e y w or d s \\
C.jejuni, Hyp gene, \\
PCR, Chicken meat \\
\hline Article Info \\
\hline $\begin{array}{l}\text { Accepted: } \\
\text { 22 July } 2018 \\
\text { Available Online: } \\
\text { 10 August } 2018\end{array}$ \\
\hline
\end{tabular}

\section{Introduction}

Campylobacter jejuni is present in the gastro intestinal tract of all animals. Due to improper slaughtering method, the carcass may get contaminated with intestinal contents.

Contaminated raw or undercooked poultry meats and/or by-products are particularly important to cause food-borne Campylobacteriosis in humans (CDC, 2005).

The prevalence of contamination with Campylobacter species were approximately $60 \%$ in any portions of raw poultry meats and by-products except for fillets and hearts. In most of the countries (both developed and developing countries), inspite of their sanitary conditions, a majority of retail poultry meats and by-products were contaminated with Campylobacter spp. C.jejuni was usually the dominant one, but the ratio of C.coli to C.jejuni varied among developed countries (Suzuki and Shigeki, 2008). The raw chicken meat has very high Campylobacter contamination levels.

Campylobacter spp. was found in higher levels in carcass-rinse or carcass-rinse plus whole skin samples (Jorgensen et al., 2002). Polymerase chain reaction (PCR) is a rapid method with both high sensitivity and specificity for rapid detection and identification of pathogenic bacteria from different food matrix. Hence, the present study is undertaken for detection of Campylobacter jejuni from chicken by using polymerase chain reaction in different zones of Chennai. 


\section{Materials and Methods}

Around 36 chicken meat samples were collected from different retail outlets of Chennai city. The samples placed in sterile polythene bags and transported hygienically to the Department of Meat Science and Technology, Madras Veterinary College, Chennai -7 in clean insulated box with ice packs. Before screening, 25 gram of meat sample was homogenized in $225 \mathrm{ml}$ of BPW and incubated at $37^{\circ} \mathrm{C}$ for 18 hours. The meat homogenate obtained was then subjected to DNA extraction using Bacterial DNA extraction kit and PCR analysis for the presence of C.jejuni by targeting Hyp gene with 500bp. A $20 \mu \mathrm{l}$ of reaction mixture was set up in $0.2 \mathrm{ml}$ PCR tube with following components such as master mix - 10 $\mathrm{\mu l}$, forward primer-1 $\mu \mathrm{l}$, reverse primer-1 $\mu \mathrm{l}$, template DNA-1 $\mu 1$ and nuclease free water-7 $\mu 1$.

The PCR amplification was carried out in Master Cycler Gradient Thermo cycler (M/s. Eppendorf, Germany) with the following cycling conditions of initial denaturation at $94^{\circ} \mathrm{C}$ for 5 minutes, followed by 30 cycles of denaturation $\left(94^{\circ} \mathrm{C}\right.$ for 30 seconds), annealing $\left(52^{\circ} \mathrm{C}\right.$ for 30 seconds) and extension $\left(72^{\circ} \mathrm{C}\right.$ for 30 seconds) and subsequently a final extension at $72^{\circ} \mathrm{C}$ for 7 minutes. The PCR product obtained was subjected to electrophoresis in 2\% Agarose gel. Ethidium bromide with concentration of $10 \mathrm{mg} / \mathrm{ml}$ was added at the rate of $5 \mu \mathrm{l} / 100 \mathrm{ml}$ of Agarose. Electrophoresis is carried out using $1 \mathrm{X}$ TAE buffer at 100 volts for 30 minutes. The gel was viewed under UV illuminator and documented using gel documentation system.

\section{Results and Discussion}

Chicken meat samples of around 36 numbers were collected from different retail outlets of Chennai. The meat homogenate obtained was subjected to DNA extraction using Bacterial DNA extraction kit and the developed PCR was used to detect Campylobacter jejuni. None of the sample showed positive for the presence of Campylobacter jejuni in the retail chicken meat by PCR (Figure 1). Screening of chicken meat from different zone wise details were given below (Table 1).

This screening study reveals that chicken meat samples collected from retail outlets for the presence of C.jejuni is to assess the effectiveness and efficiency of the PCR technique and the level of processing of retail chicken meat. The 36 chicken meat samples collected from different areas of Chennai city were not positive for Campylobacter jejuni. Campylobacter jejuni are found in domestic animals and also in raw poultry meat (Humphrey et al., 2007). In this study, the Hyp (Hippurate) gene was targeted for PCR amplification of Campylobacter jejuni since the gene was specific and is responsible for hippurate hydrolysis which is a specific biochemical and confirmatory test. Results of this study revealed species specific bands of 500 bp in 2\% agarose gel (Nakari et al., 2008).

Similar results were reported by targeting hipO gene for detection of C. jejuni subsp. jejuni (Rahimi et al., 2010). He found higher prevalence of Campylobacter (61.7\%) in chicken meat from retail markets of Iran. A study was conducted and found that the level of contamination of poultry meat with Campylobacter jejuni was 50.9\% (Atanassova and Ring, 1997). Around 1 in 1000 infections leads to Guillain-Barre syndrome (GBS), the risk increased to around 1 in 200 for patients infected with a particular $C$. jejuni, Penner type HS:19 (Nachamkin, 2002). An overlap of $34 \%$ between sero-/genotype combinations in sporadic $C$. jejuni infections in chicken flocks at slaughter during a seasonal peak (Karenlampi et al., 2003). 
Table.1 Screening of chicken meat samples collected from different retail outlets of Chennai

\begin{tabular}{|c|c|c|c|}
\hline \multirow{2}{*}{ Zone } & Name & $\begin{array}{c}\text { No. of } \\
\text { samples }\end{array}$ & $\begin{array}{c}\text { No. of positive samples by m-PCR } \\
\text { Campylobacter jejuni }\end{array}$ \\
\hline 1 & Thiruvottiyur & 5 & - \\
\hline 2 & Madhavaram & 5 & - \\
\hline 3 & Royapuram & 5 & - \\
\hline 4 & Ambattur & 5 & - \\
\hline 5 & Anna nagar & 5 & - \\
\hline 6 & Teynapet & 5 & - \\
\hline 7 & Kodambakkam & 6 & - \\
\hline
\end{tabular}

Fig.1

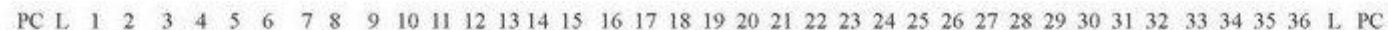

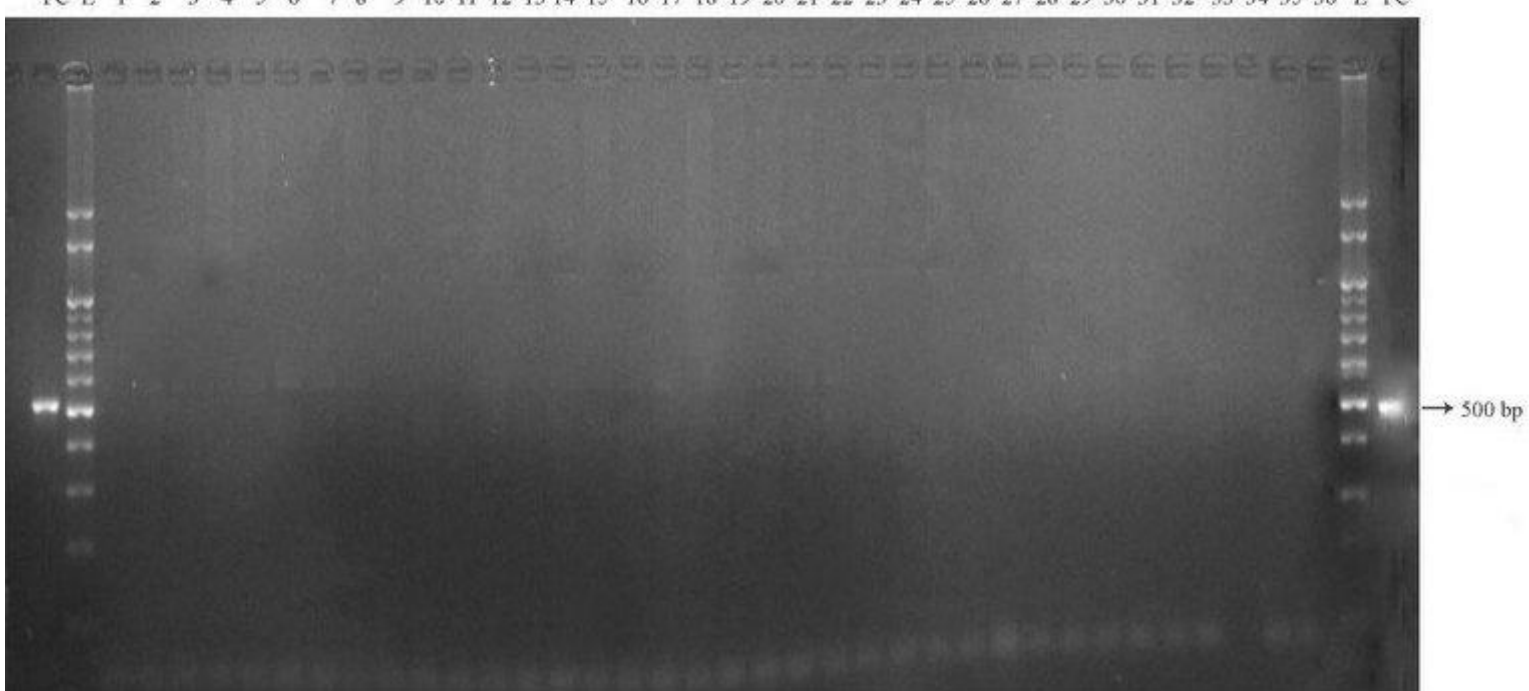

Note: L: 100 bp DNA Ladder, 1-36: Sample result showing absence of Campylobacter jejuni in chicken meat, PC: Positive control of Campylobacter jejuni with 500bp, NC: Negative control

\section{Acknowledgments}

I am very much grateful to my Honorable guide, all other department staffs and my friends and colleagues who have helped me in collecting samples from different areas of Chennai and carrying the PCR.

\section{References}

Atanassova, V., and Ring, Ch. 1997. Campylobacter spp. in slaughter poultry and in hunted game fowl. World congress on Food Hygiene. WAVFH. The Hague, August 24-29, 1997. Proceedings. Wageningen Pers. Wagenigen, 1997, 193.

Centre for Disease Control and Prevention (CDC), 2005.

Humphrey, T., Sarah, O.B. and Mogens, M. 2007. Campylobacters as zoonotic pathogens: A food production perspective. International Journal of Food Microbiology, 117: 237-257.

Jorgensen, F., Bailey, R., Williams, S., Henderson, P., Wareing, D.R., Bolton, 
F.J., Frost, J.A., L. Ward, L. and Humphrey, T.J, 2002. Prevalence and numbers of Salmonella and Campylobacter spp. on raw, whole chickens in relation to sampling methods. International Journal of Food Microbiology, 76: 151-164.

Karenlampi, R., Rautelin, H., Hakkinen, M. and Hanninen, M.L. 2003. Temporal and geographical distribution and overlap of Penner heat-stable serotypes and pulsed-field gel electrophoresis genotypes of Campylobacter jejuni isolates collected from humans and chickens in Finland during a seasonal peak. Journal of Clinical Microbiology, 41: 4870-4872.

Nachamkin, I., (2002). Chronic effects of Campylobacter infection. Microbes and Infection, 4: 399- 403.
Nakari, U.M., Puhakka, A. and Siitonen, A. 2008. Correct identification and discrimination between Campylobacter jejuni and $C$. coli by a standardized hippurate test and species-specific polymerase chain reaction. European Journal of Clinical Microbiology and Infectious Disease, 27: 513-518.

Rahimi, E., Kazemeini, H.R., Saman, S., Karim, A., Momeni, M. and Riahi, M. 2010. Detection and identification of Campylobacter spp. from retail raw chicken, turkey, sheep and goat meat in Ahvaz, Iran. African Journal of Microbiology Research, 4: 1620-1623.

Suzuki, H. and Shigeki, Y. 2008. Campylobacter contamination in retail poultry meats and by-products in the world: A literature survey. Public Health.

\section{How to cite this article:}

Satheesh Raja, S., V. Apparao, R. Narendra Babu and Balamurugan, N. 2018. Detecting the Occurrence of Campylobacter jejuni in Chicken Meat by PCR in Retail Outlets of Chennai, India. Int.J.Curr.Microbiol.App.Sci. 7(08): 4174-4177.

doi: https://doi.org/10.20546/ijcmas.2018.708.436 